\title{
Biphasic effect of PMSG on lactation in the rat
}

\author{
D. J. Flint \\ Hannah Research Institute, Ayr, Scotland KA6 SHL, U.K.
}

\begin{abstract}
Summary. A single injection of PMSG to rats on Day 10 of lactation produced a biphasic inhibitory effect on litter growth. The initial effect (24-72 h) occurred in conjunction with a rise in the concentration of oestradiol-17ß and $\mathrm{LH}$ and a decline in serum prolactin, whereas the secondary effect ( $96 \mathrm{~h}$ onward) occurred in conjuction with an increase in oestradiol-17 $\beta$ and prolactin concentrations. Progesterone implants prevented the initial, but not the secondary, effect of PMSG on lactation without producing any effect on serum oestradiol-17 $\beta$ concentrations. The results suggest that the initial effect of PMSG on litter growth may be produced by changes in pituitary prolactin and gonadotrophin secretion rather than by an effect of oestrogens acting on the mammary gland.
\end{abstract}

\section{Introduction}

The deleterious effect of pregnant mare's serum gonadotrophin (PMSG) on lactation in the rat was established many years ago (Enzmann \& Pincus, 1933; Connon, 1937; Edelmann \& Gaunt, 1941). The indirect nature of its action has been clearly illustrated by the lack of effect of PMSG in ovariectomized animals (de Jongh \& Van der Woerd, 1939; Edelmann \& Gaunt, 1941). This led to the proposal that the mode of action of PMSG was through a stimulatory effect on oestrogen secretion which in turn affected the mammary gland. Such inhibitory effects of oestrogens on the mammary gland are well established for a variety of species (Cowie, Folley, Malpress \& Richardson, 1952; Bruce, Cofré \& Ramirez, 1973; Zamora, Mendoza \& Ramirez, 1975).

In the present study the effects of PMSG on hormone concentrations in lactating rats were studied.

\section{Materials and Methods}

Nulliparous female Wistar rats weighing $180-250 \mathrm{~g}$ were mated at parturition (Day 1). All females were housed individually with their litter, which was adjusted to 6 in number, and food and water were available ad libitum. They were maintained at a temperature of $22^{\circ} \mathrm{C}$ with a lighting regimen of $12 \mathrm{~h}$ light $: 12 \mathrm{~h}$ dark, lights on at $08: 30 \mathrm{~h}$.

On Day 10 of lactation at 10:00 h, 6 animals received 200 i.u. PMSG (Folligon: Intervet Labs, Cambridge, U.K.) s.c. in $0.2 \mathrm{ml}$ saline $(9 \mathrm{~g} \mathrm{NaCl} / 1) ; 5$ animals received PMSG plus a $200 \mathrm{mg}$ disc of pure progesterone (Sigma, London U.K.) s.c. in the nape of the neck whilst they were under halothane anaesthesia; and 6 control rats received $0.2 \mathrm{ml}$ saline s.c. and a sham implant.

All litters were weighed daily and daily vaginal smears were taken from the dams. On Day 14, 4 days after treatment, laparotomy was performed with halothane anaesthesia and the ovaries were examined through a single abdominal incision for the presence of mature follicles and any newly formed corpora lutea. 
Blood samples $(0.5-1 \mathrm{ml})$ were taken at approximately 10:00 $\mathrm{h}$ from the tail of rats under halothane anaesthesia $; 2 \mathrm{ml}$ blood samples were obtained when oestradiol-17 $\beta$ determinations were to be made. Blood was allowed to clot at room temperature for $30 \mathrm{~min}$ and then serum was obtained by centrifugation at $1000 \mathrm{~g}$ for $10 \mathrm{~min}$ and stored at $-20^{\circ} \mathrm{C}$ until used for hormone analyses. Serum prolactin, LH and progesterone concentrations were determined by radioimmunoassays as described previously (Flint, Sinnett-Smith, Clegg \& Vernon, 1979; Flint \& Ensor, 1980). In the progesterone assay there was cross-reaction with $5 \alpha$-pregnanedione $(2.5 \%)$ and corticosterone $(0 \cdot 1 \%)$. The sensitivity was $200 \mathrm{pg} /$ tube and the inter- and intra-assay coefficients of variation were 8 and $5 \%$ respectively. Serum prolactin was expressed in terms of ng NIAMDD-rat-PRL-RP1/ml and $\mathrm{LH}$ as ng NIAMDD-LH-RP1/ml. The sensitivities of the assays were $0.4 \mathrm{ng}$ prolactin/tube and $1 \mathrm{ng} \mathrm{LH} /$ tube and inter- and intra-assay coefficients of variation were 11 and $4 \%$ respectively for prolactin and 12 and $6 \%$ respectively for $\mathrm{LH}$. Serum oestradiol-17 $\beta$ concentration was determined in a fashion similar to that of progesterone with the following modifications: $500 \mu \mathrm{l}$ serum were extracted with $2.5 \mathrm{ml}$ diethyl ether (BDH, Poole, Dorset, U.K.). The ether was evaporated to dryness and the residue redissolved in $200 \mu$ assay buffer. $\left[2,4,6,7-{ }^{3} \mathrm{H}\right]$ Oestradiol-17 $\beta$ (sp. act. 85$110 \mathrm{Ci} / \mathrm{mmol}$; Amersham International, Bucks, U.K.) and antiserum to oestradiol-17 $\beta$ (Wellcome Reagents Ltd, London, U.K.) were used. Major cross-reactants in the assay were oestrone (5\%) and

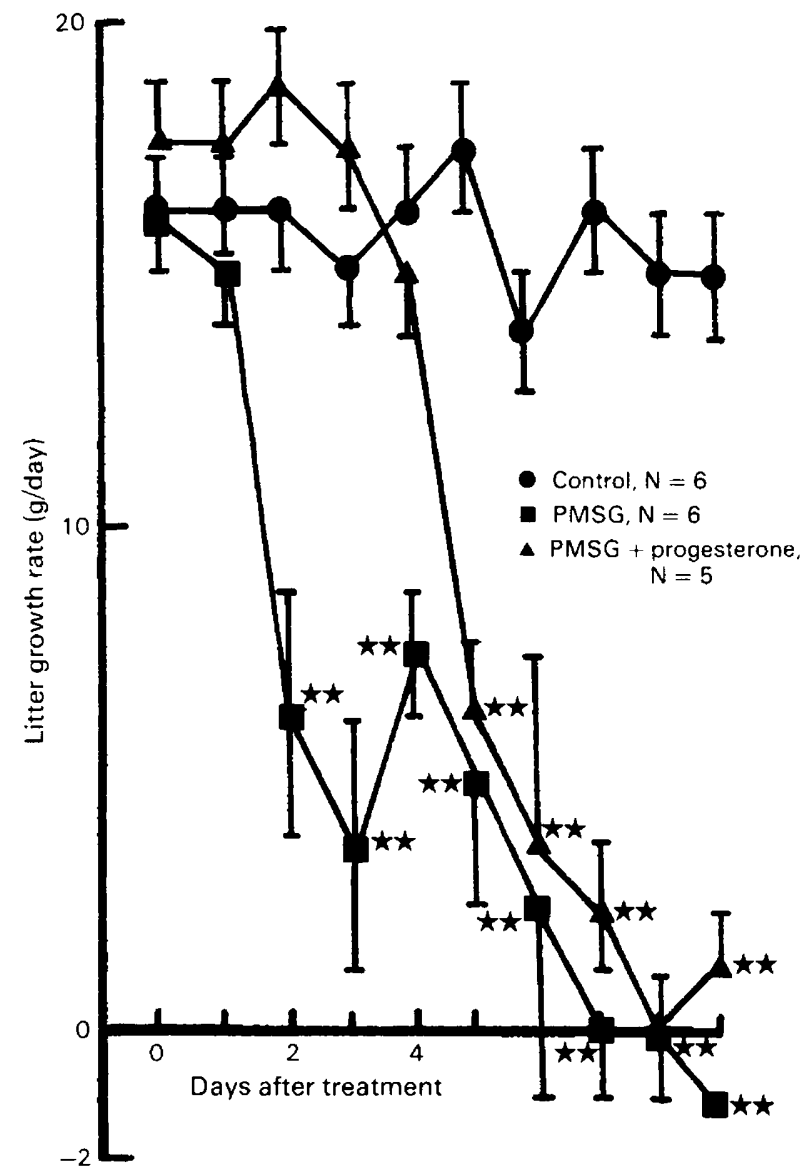

Text-fig. 1. Litter growth rates in lactating rats. Values are means \pm s.e.m. (where large enough to record). ${ }^{*}, P<0.05 ;{ }^{* *}, P<0.01$ compared with pre-treatment values (Student's paired $t$ test). 
oestriol $(0 \cdot 7 \%)$. Intra- and inter-assay coefficients of variation were 9 and $15 \%$ respectively. Sensitivity of the assay was $5 \mathrm{pg} / \mathrm{ml}$.

Statistical comparisons were made using Student's paired $t$ test.

\section{Results}

Text-figure 1 illustrates the inhibitory effect of a single injection of PMSG on litter growth rate. There appeared to be a biphasic effect of PMSG with the initial effect evident after $24-48 \mathrm{~h}$ and reaching a nadir after $48-72 \mathrm{~h}$. This was followed by a significant increase in litter growth $(P<$ 0.05 ) over the next $24 \mathrm{~h}$ with a second more dramatic decline over the ensuing 5 days. The initial effect of PMSG but not the secondary effect was absent when animals also received progesterone implants (Text-fig. 1).

PMSG induced a large sustained increase in oestradiol-17 $\beta$ from new follicles developing within the ovary (Text-fig. 2). Serum prolactin and progesterone concentrations declined significantly after $48 \mathrm{~h}$ in PMSG-treated rats whereas serum LH concentrations increased. After 96 $h$ these changes (with the exception of serum oestradiol-17 $\beta$ ) were reversed and ovulation appeared to have taken place as judged by the presence of a new set of corpora lutea within the ovaries of PMSG-treated rats, although all the ovaries of PMSG-injected rats still possessed some large
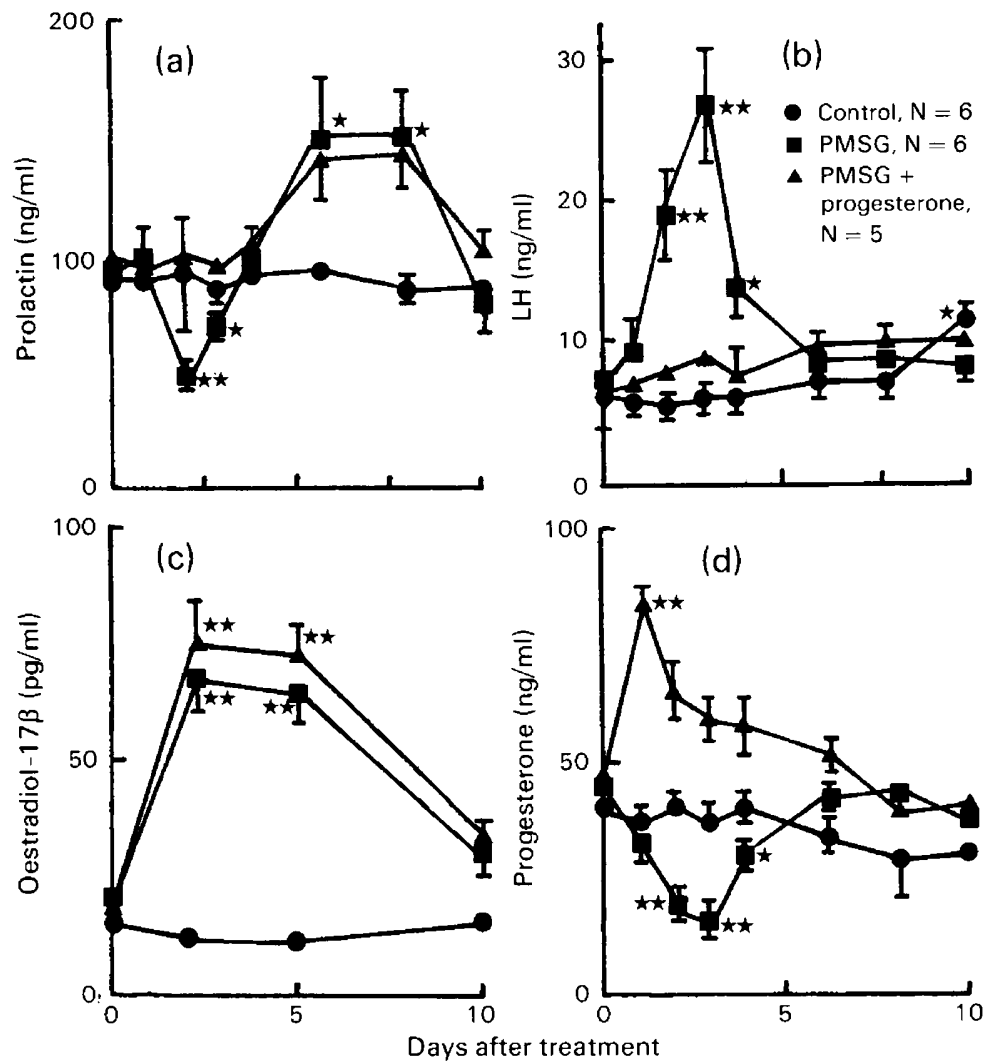

Text-fig. 2. Changes in (a) serum prolactin, (b) serum LH, (c) serum oestradiol-17 $\beta$, (d) serum progesterone concentrations in lactating rats. Values are means \pm s.e.m. (where large enough to record). ${ }^{*}, P<0.05 ;^{* *}, P<0.01$ compared with pre-treatment values (Student's paired $t$ test). 
follicles which had not ovulated. Progesterone implants completely prevented the changes in serum prolactin and LH concentrations induced by PMSG during the first $72 \mathrm{~h}$ but did not prevent the increase in the serum concentration of oestradiol-17ß. Progesterone also prevented the appearance of new corpora lutea $96 \mathrm{~h}$ after PMSG injection, suggesting that ovulation had been inhibited. By 6-8 days after PMSG injection the concentrations of prolactin and oestradiol-17 $\beta$ were significantly elevated irrespective of whether the animals received progesterone implants.

\section{Discussion}

These results reveal a biphasic effect of a single injection of PMSG on lactation in the rat. The second more prolonged effect of PMSG on lactation appeared to be most easily interpreted in terms of an indirect effect mediated by an inhibitory effect of oestrogen on the mammary gland, as suggested previously (de Jongh \& Van der Woerd, 1939; Edelmann \& Gaunt, 1941), because serum oestradiol-17 $\beta$ concentrations were elevated and lactation was inhibited despite elevated serum prolactin concentrations. Increased serum prolactin concentrations in response to oestrogens are well documented (Desclin \& Koulischer, 1960; Nicoll \& Meites, 1962; Kanematsu \& Sawyer, 1963) and a direct inhibitory effect of oestrogen on lactation has been shown (Bruce et al., 1973; Zamora et al., 1975).

The initial effect of PMSG, however, did not appear to be produced by a direct effect of oestradiol-17 13 on the mammary gland. Although oestradiol-17 $\beta$ levels were increased during the first $48 \mathrm{~h}$ after PMSG treatment there was also a significant reduction in the serum concentrations of prolactin, which in itself would be expected to lead to a decline in lactation (Dohler \& Wuttke, 1974). Further support for this suggestion came from the finding that progesterone implants were able to prevent the initial effect of PMSG despite their inability to influence serum oestradiol-17 $\beta$ levels. Progesterone does not inhibit the direct effect of oestrogens on the mammary gland; progesterone implants are unable to prevent the inhibitory effects of oestrogen injections on lactation (D. J. Flint, unpublished observations).

The initial effect of PMSG on lactation was accompanied by an increase in serum LH concentrations and it has been proposed that prolonged secretion of LH and prolactin may be mutually exclusive. Prolactin secretion is reduced in ovariectomized rats in which gonadotrophin release is enhanced (Amenomori, Chen \& Meites, 1970) and can be normalized by inhibiting gonadotrophin secretion with methallibure, a non-steroidal gonadotrophin inhibitor (Ben-David, Danon \& Sulman, 1971). The initial effect of PMSG may therefore be produced by an increase in oestradiol-17 $\beta$ secretion which produces changes leading to an increase in $\mathrm{LH}$ release and a decrease in prolactin secretion. The fact that progesterone implants inhibited LH secretion and prevented the initial effect of PMSG on lactation lends further support to this hypothesis. Progesterone and oestrogens produce their effects on LH secretion at least in part by an action on the hypothalamus, and since the tonic hypothalamic controls of $\mathrm{LH}$ and prolactin secretion from the pituitary are stimulatory and inhibitory respectively it may be that the hypothalamic conditions required for increased basal LH secretion preclude the secretion of large amounts of prolactin. That LH itself does not inhibit lactation or prolactin secretion directly was evident from a lack of effect of exogenous hCG on lactation (results not shown).

In summary, the effects of PMSG on lactation appear to be mediated via increased oestrogen secretion since they are absent in ovariectomized rats. The inhibitory effect of oestradiol on lactation, however, appears to be biphasic, resulting initially from an increase in serum LH and an inhibition of prolactin secretion and later from a direct effect, produced despite elevated serum concentrations of prolactin, on the mammary gland. 


\section{References}

Amenomori, Y., Chen, C.L. \& Meites, J. (1970) Serum prolactin levels in rats during different reproductive states. Endocrinology 86, 506-510.

Ben-David, M., Danon, A. \& Sulman, F.G. (1971) Evidence of antagonism between prolactin and gonadotrophin secretion: effect of methallibure on perphenazine-induced prolactin secretion in ovariectomized rats. J. Endocr. 51, 719-725.

Bruce, J.O., Cofré, X. \& Ramirez, V.D. (1973) Effect of locally implanted oestrogen on the response of the rat's lactating mammary gland to oxytocin. Acta endocr., Copenh. 73, 700-712.

Connon, F.E. (1937) Effect of anterior pituitary-like hormone on lactation in the albino rat. Proc. Soc. exp. Biol. Med. 37, 52-55.

Cowie, A.T., Folley, S.J., Malpress, F.H. \& Richardson, K.C. (1952) Studies on the hormonal induction of mammary growth and lactation in the goat. $J$. Endocr. 8, 64-88.

de Jongh, S.E. \& Van der Woerd, L.A. (1939) Is there an extragonadal gonadotrophic hormone which checks lactation? Acta brev. neerl. Physiol. 9, 26-27.

Desclin, L. \& Koulischer, L. (1960) Action d'un traitement oestrogenique sur la teneur en prolactin de l'hypophyse greffee chez la rat. C. r. Séanc. Soc. Biol. 154, $1515-1517$.
Dohler, K.D. \& Wuttke, W. (1974) Total blockade of phasic pituitary prolactin release in rats: effect on serum LH and progesterone during the estrous cycle and pregnancy. Endocrinology 94, 1595-1600.

Edelmann, A. \& Gaunt, R. (1941) Inhibition of lactation in the rat. Physiol. Zool. 14, 373-378.

Enzmann, E.V. \& Pincus, G. (1933) The effect on lactating mice of injecting an extract of the urine of pregnancy. Am. J. Physiol. 103, 30-33.

Flint, D.J. \& Ensor, D.M. (1980) Effects of prolactin and the suckling stimulus on implantation and $\mathrm{LH}$ secretion in rats. J. Reprod Fert. 58, 443-448.

Flint, D.J., Sinnett-Smith, P.A., Clegg, R.A. \& Vernon, R.G. (1979) Role of insulin receptors in the changing metabolism of adipose tissue during pregnancy and lactation in the rat. Biochem. J. 182, 421-427.

Kanematsu, S. \& Sawyer, C.H. (1963) Effects of intrahypothalamic and intrahypophysial estrogen implants on pituitary prolactin and lactation in the rabbit. Endocrinology 72, 243-252.

Nicoll, C.S. \& Meites, J. (1962) Estrogen stimulation of prolactin production by rat adenohypophysis in vitro. Endocrinology 70, 272-277.

Zamora, A.J., Mendoza, A.S. \& Ramirez, V.D. (1975) Ultrastructure of the mammary gland in lactating rats after local implantation of oestrogen. J. Endocr. 66, 177-182.

Received 21 April 1983 